\title{
Plesiosoricids from early Oligocene fissure fillings in South Germany, with remarks on plesiosoricid phylogeny
}

\author{
Reinhard Ziegler \\ Acta Palaeontologica Polonica 54 (3), 2009: 365-371 doi: http://dx.doi.org/10.4202/app.2008.0061
}

The plesiosoricids from two fissure fillings from Möhren on the Franconian in South Germany are described. All belong

to Butselia biveri. Möhren 12 correlates with the early Oligocene standard level Soumailles, corresponding to the

Paleogene mammal unit MP 21, and Möhren 13 with the standard level Villebramar, which corresponds to MP 22. These occurrences represent the first record of the genus Butselia in Germany. A review of the known plesiosoricid species and a cladistic analysis of Butselia and Plesiosorex are presented. It shows the basal position of Butselia with respect to Plesiosorex, and the basal position of Plesiosorex soricinoides with respect to the other Plesiosorex species.

Key words: Mammalia, Lipotyphla, Plesiosoricidae, Butselia, cladistic, systematics, Germany.

Reinhard Ziegler [ziegler.smns@ naturkundemuseum-bw.de], Staatliches Museum für Naturkunde Stuttgart, Rosenstein 1, D-70191 Stuttgart, Germany.

This is an open-access article distributed under the terms of the Creative Commons Attribution License (for details please see creativecommons.org), which permits unrestricted use, distribution, and reproduction in any medium, provided the original author and source are credited. 